\title{
Mercimek Proteini İzolatı ve Unu Kullanılarak Bitkisel Bazlı Fırıncılık Ürünlerinin Geliştirilmesi
}

\author{
Burcu Utku ${ }^{1}$, Arya Deniz Ayan ${ }^{2}$, Zeynep Saliha Güneş ${ }^{3}$, Aslı Can Karaça ${ }^{4 *}$
}

Geliş / Received: 08/11/2019

Kabul / Accepted: 22/06/2020

ÖZ

Bu çalışmada, mercimek proteini izolatı ve unu kullanılarak bitkisel bazlı fırıncılık ürünlerinin geliştirilmesi ve bu bileşenlerin kullanım oranının son ürünlerin kalite özelliklerine etkilerinin incelenmesi amaçlanmıştır. Mercimek proteini izolatı, yerel üreticiden temin edilen mercimekten alkali ekstraksiyon/izoelektrik çöktürme yöntemi ile elde edilmiştir. Mercimek proteini izolatı (\%1-5) içeren kek numunelerinin nem ve yağ içeriğinin kontrole göre düşük, protein içeriğinin ise kontrolden yüksek olduğu görülmüştür. İzolat içeren numunelerde kek verimi kontrole göre düşük, pişme kaybı yüksek bulunurken; \%3 ve 5 oranında izolat içeren numunelerin yüksekliğinin kontrole benzer olduğu görülmüştür. Hem kek kabuğu hem de içi için renk farkı artan izolat oranı ile artmıştır. Bitkisel bazlı kek formülasyonunda mercimek proteini izolatı uygulaması ürünün tekstür özelliklerinde farklılıklara neden olarak daha sert ve çiğnenebilirliği düşük bir yapı oluşturmuştur. İzolat içeren kek numunelerinin duyusal özellikleri kontrolden farklı bulunmuştur. Kraker formülasyonunda kullanılan mercimek unu oranı (\%20-50) arttıkça numunelerin protein içeriği artmış, nem ve yağ içerikleri düşmüştür. Formülasyonda mercimek unu oranı arttıkça numunelerin kontrol ile aralarındaki renk farkı da artmıştır. Krakerde mercimek unu kullanımı daha yumuşak ve esnek; fakat çiğnenebilirliği düşük bir yapı oluşturmuştur. Buna karşılık; \%20 ve 40 oranında mercimek unu içeren kraker numuneleri duyusal özellikler açısından kontrol numunesine benzer bulunmuştur. Elde edilen bulgular, ülkemize özgü mercimek türlerinin çeşitli fırıncılık ürünlerinin formülasyonlarında iyileştirme yapılarak bitkisel protein kaynağı olarak değerlendirilebileceğini göstermiştir.

\footnotetext{
1İletişim: utku@itu.edu.tr (https://orcid.org/0000-0003-4357-3805)

İstanbul Teknik Üniversitesi, Kimya-Metalurji Fakültesi, Gıda Mühendisliği Bölümü, İstanbul

2İletişim: ayana@itu.edu.tr (https://orcid.org/0000-0001-9127-8734)

İstanbul Teknik Üniversitesi, Kimya-Metalurji Fakültesi, Gıda Mühendisliği Bölümü, İstanbul

3̇letişim: zeynep.gunes@izu.edu.tr (https://orcid.org/0000-0002-4219-2368)

İstanbul Sabahattin Zaim Üniversitesi, Mühendislik ve Doğa Bilimleri Fakültesi Gıda Mühendisliği Bölümü, İstanbul

4*Sorumlu yazar iletişim: cankaraca@itu.edu.tr (https://orcid.org/0000-0002-4137-0644)

İstanbul Teknik Üniversitesi, Kimya-Metalurji Fakültesi, Gıda Mühendisliği Bölümü, İstanbul
} 


\title{
Development of Plant-Based Bakery Products Using Lentil Protein Isolate and Flour
}

\begin{abstract}
The aim of this study was to develop plant-based bakery products using lentil protein isolate (1-5\%) and lentil flour $(20-50 \%)$ and to investigate the effects of these compounds on quality characteristics of final products. Lentil protein isolate was produced from local lentils using alkali extraction/isoelectric precipitation method. Moisture and fat content of cake samples with lentil protein isolate were lower compared to control; whereas their protein content was higher. Isolate-containing cake samples had lower cake yield and higher cooking loss compared to control. Height of cake samples with 3 and 5\% isolate was found to be similar to control. Colour difference increased as the isolate amount increased. Isolate-containing cake samples were harder and had lower chewiness compared to control. Sensory properties of cake samples with isolate were found to be different than the control sample. As the lentil flour ratio increased from 20 to $50 \%$ in cracker formulations, protein content of the products increased. However moisture and fat content decreased. Use of lentil flour in crackers resulted in a colour difference which increased as the amount of lentil flour increased. Crackers with lentil flour were softer and more elastic; however their chewiness was lower compared to control. On the other hand, crackers with 20 and $40 \%$ lentil flour were found to be similar to control in terms of sensory properties. Findings of the present study indicate that lentils grown in our country can be utilized as a plant protein source in bakery product formulations with some modifications.
\end{abstract}




\section{GİRIŞ}

Günümüzde bitkisel bazlı beslenme tercihlerine yönelik eğilimin artması, bitkisel kaynaklı hammaddelerin daha ulaşılabilir ve ucuz olması ve sağlık ile ilgili gerekliliklerden dolayı bitkisel kaynaklı proteinlere yönelik ilgi artmıştır. Güncel çalışmalarda özellikle yeni geliştirilen gıda ürünlerinin formülasyonlarında bitkisel kaynaklı proteinler tercih edilmeye başlanmıștır. Buna ek olarak var olan ürünlerin formülasyonlarındaki proteinlere bitkisel kaynaklı alternatifler geliştirmeye yönelik çalışılmalar da mevcuttur. Dolayısıyla baklagiller, tahıllar, yağlı tohumların küspeleri ve kuruyemişler gibi çeşitli hammaddelerden elde edilen bitkisel kaynaklı proteinlerin bileşimi, fizikokimyasal ve fonksiyonel özelliklerine yönelik bilimsel çalışmalar artmakta, ürün çalışmaları perspektifi de zamanla gelişmektedir. Çözünürlük, su ve yağ tutma, emülsiyon oluşturma, köpük oluşturma ve jelleşme gibi çeşitli fonksiyonel özellikleri ile baklagillerden elde edilen proteinler pek çok gıda ürününde bileşen olanak kullanılma potansiyeline sahiptirler [1].

Ülkemizde nohuttan sonra en yüksek miktarda üretilen baklagil olan mercimeğin (Lens culinaris Medik) 2018 yılı üretim miktarı 353000 tonu bulmuştur [2]. Mercimek, soya fasulyesinden sonra en yüksek oranda protein içeren baklagildir [3]. Mercimeğin protein içeriği genetik faktörlerden ve çevre koşullarından etkilenmekte olup; \%22-30 arasında değişmektedir [4]. Mercimek proteinleri ağırlıklı olarak globulinler (\%50-65) ve albuminlerden (\%10-25) oluşmaktadır [1,5]. Baklagillerden asit veya alkali ile ekstraksiyon/izoelektrik çöktürme, tuz ile ekstraksiyon/misel çöktürme, hava ile ayırma ve ultrafiltrasyon gibi çeşitli metotlar kullanılarak protein konsantre ve izolatları üretilmektedir [1]. Mercimek proteinlerinin su ve yağ tutma kapasitesi, köpük oluşturma ve emülsiyon oluşturma gibi fonksiyonel özellikleri çeşitli araştırmacılar tarafından incelenmiştir [5-7].

Bu çalışmada, farklı oranlarda mercimek proteini izolatı ve mercimek unu kullanımının fırıncılık ürünlerinin çeşitli kalite özelliklerine etkisinin incelenmesi amaçlanmıştır. Tamamen bitkisel kaynaklı hammaddelerin kullanıldığı ürün formülasyonları ile çalışılmış; mercimek proteini izolatı uygulaması için model ürün olarak kek; mercimek unu uygulaması için ise kraker seçilmiştir.

\section{MATERYAL VE METOT}

\section{A. Malzemeler}

Çalışmada kullanılan mercimek unu, yerel üreticiden temin edilen mercimeğin laboratuvar ölçekli öğütücüde öğütülmesi ile elde edilmştir. Kek ve kraker üretiminde kullanılan hammaddeler yerel marketlerden temin edilmiştir. Analizlerde kullanılan kimyasallar analitik saflıktadır.

\section{B. Mercimek Proteini İzolatı Eldesi}

Mercimek proteini izolatı, Joshi ve diğ. [7]'nin belirttiği metot kullanılanarak elde edilmiştir. Mercimek unu ve distile su 1:10 oranında karıştırılmıştır. Ardından $0,1 \mathrm{M} \mathrm{NaOH}$ çözeltisi eklenerek pH değeri 9'a çıkarılan karışım, oda sıcaklığında manyetik karıştırıcı yardımı ile 1 saat süreyle karıştırılmıştır. Karışım 8000 rpm'de $4^{\circ} \mathrm{C}^{\prime}$ de 20 dakika boyunca santrifüj edilmiş̧ir. Santrifüj sonunda çözünmeyen faz uzaklaştırılmıştır. Süpernetant toplanarak pH'ı $1 \mathrm{M}$ HCI ile 4,5'a ayarlanmış ve 8000 rpm'de $4^{\circ} \mathrm{C}^{\prime}$ de 20 dakika süreyle santrifüj edilmiştir. Santrifüj sonunda sıvı faz uzaklaştırılırken çöken faz petri kaplarına aktarılmış ve dondurarak kurutma yöntemiyle kurutulmuştur. Elde edilen toz formdaki protein izolatı sıkıca kapalı bir kap içerisinde hava almayacak şekilde $4^{\circ} \mathrm{C}$ 'de muhafaza edilmiştir.

\section{Kek ve Kraker Numunelerinin Bileşimi ve Hazırlanması}

Kek numunelerinin hazırlanmasında Jarpa-Parra ve diğ. [5]'nin çalışmasında kullanılan formülasyondan yararlanılmış; yumurta ve süt içeren kontrol örneği ve \%1, 3 ve 5 oranlarında mercimek proteini izolatı içeren örnekler olmak üzere toplam dört farklı örnek hazırlanmıştır (Tablo 1). Öcelikle mercimek proteini izolatı su içerisinde çözündürülmüştür. İzolat çözeltisine şeker eklenerek elektrikli karıştııııı yardımı ile 2 dakika boyunca karıştırılarak köpük oluşumu sağlanmıştır. Ardından toz bileşenler (buğday unu, kakao, kabartma tozu, vanilin, karbonat) ve sıvı yağ eklenerek 2 dakika daha karıştııılmıştır. Elde edilen homojen karışım karton kek pişirme kalıplarına aktarılmış ve önceden ısıtılmış elektrikli fırında $180^{\circ} \mathrm{C}$ 'de 40 dakika süreyle pişirilmiştir. 
Tablo 1. Kek numunelerinin hazırlanmasında kullanılan formülasyonlar.

\begin{tabular}{lcccc}
\hline \multicolumn{1}{c}{ Bileşen (g/100 g) } & Kontrol & \%1 İzolat & \%3 İzolat & \%5 İzolat \\
\hline Buğday unu & 18,50 & 18,50 & 18,50 & 18,50 \\
Şeker & 23,00 & 23,00 & 23,00 & 23,00 \\
Mercimek proteini izolatı & - & 1,00 & 3,00 & 5,00 \\
Su & - & 39,00 & 37,00 & 35,00 \\
Yumurta & 13,00 & - & - & - \\
Süt & 27,00 & - & - & - \\
Ayçiçek yağ1 & 14,00 & 14,00 & 14,00 & 14,00 \\
Kabartma tozu & 0,20 & 0,20 & 0,20 & 0,20 \\
Vanilin & 1,35 & 1,35 & 1,35 & 1,35 \\
Karbonat & 0,20 & 0,20 & 0,20 & 0,20 \\
Kakao & 2,75 & 2,75 & 2,75 & 2,75 \\
\hline
\end{tabular}

Mercimek unu kullanılarak hazırlanan kraker örneklerinin formülasyonlarının belirlenmesinde Millar ve diğ. [8] tarafından gerçekleştirilen çalışmadan faydalanılmıştır. Buğday unu içeren kontrol örneği ve \%20, \%40 ve \%50 oranında mercimek unu içeren örnekler olmak üzere toplam dört farklı formülasyon hazırlanmıştır (Tablo 2). Belirli oranlarda buğday unu, mercimek unu, su, zeytin ezmesi, tuz, şeker ve kabartma tozu karıştırılarak hamur haline getirilmiştir. Bu hamur düz bir tepsiye yaklaşık 2,5 mm kalınlığında yayılarak kare şeklinde kesilmiş ve önceden 1 sıtılmış elektrikli fırında $175^{\circ} \mathrm{C}$ 'de 15 dakika süreyle pişirilmiştir.

Tablo 2. Kraker numunelerinin hazırlanmasında kullanılan formülasyonlar.

\begin{tabular}{lcccc}
\hline Bileşen (g/100 g) & Kontrol & \%20 mercimek unu & \%40 mercimek unu & \%50 mercimek unu \\
\hline Buğday unu & 57,00 & 45,60 & 34,20 & 28,50 \\
Mercimek unu & - & 11,40 & 22,80 & 28,50 \\
Zeytin ezmesi & 14,20 & 14,20 & 14,20 & 14,20 \\
Su & 25,60 & 25,60 & 25,60 & 25,60 \\
Şeker & 1,10 & 1,10 & 1,10 & 1,10 \\
Tuz & 1,70 & 1,70 & 1,70 & 1,70 \\
Kabartma tozu & 0,40 & 0,40 & 0,40 & 0,40 \\
\hline
\end{tabular}

\section{Kalite Özelliklerinin Belirlenmesi}

1) Besin Öğeleri Kompozisyonu: Mercimek unu, mercimek proteini izolat, kek ve kraker numunelerinin besin öğeleri kompozisyonu AOAC [9] resmi metotları esas alınarak belirlenmiştir.

2) Kek Numunelerine Uygulanan Analizler: Kek hamurunun özgül ağırlığı Paraskevopoulou ve diğ. [10] tarafından tanımlanan metot esas alınarak; kek hamurunun ağırlığının, eşit hacimdeki saf suyun ağırlığına bölünmesi ile hesaplanmıştır. Kek verimi ve pişme kaybı Palamutoğlu ve diğ. [11] tarafından tanımlanan metoda göre belirlenmiştir. Kek yüksekliği numuneler ortadan dikey olarak kesilerek ve en yüksek noktanın yüksekliği ölçülerek belirlenmiştir [5]. Tekstür Profili Analizi (TPA) pişirme işleminin üzerinden yaklaşık 3 saat geçtikten sonra keklere Ratnayake ve diğ. [12] tarafından tanımlanan metotta bazı değişiklikler yapılarak, Lloyd TAPlus tekstür analiz cihazı (Lloyd, İngiltere) kullanılarak gerçekleştirilmiştir. Kek numunelerinin renk ölçümü ve kontrol numunesi ile aralarındaki toplam renk farkı ( $\left.\Delta \mathrm{E}^{*}\right)$ hesabı, Lin ve diğ. [13] tarafından tanımlanan metoda göre, Konica Minolta Chroma Meter CR-400 renk ölçüm cihazı (Konica Minolta, Japonya) kullanılarak gerçekleştirilmiştir. Ölçüm sonuçları CIE $\left(L^{*}, a^{*}, b^{*}\right)$ sistemi ile ifade edilmiştir. Esmerleşme indeksi ise Shaabani ve diğ. [14] tarafından tanımlanan metoda göre hesaplanmıştır. 
3) Kraker Numunelerine Uygulanan Analizler: Kraker numunelerinin Tekstür Profili Analizi (TPA) Millar ve diğ. [15] tarafından tanımlanan metoda göre, Lloyd TAPlus tekstür analiz cihazı (Lloyd, İngiltere) kullanılarak gerçekleştirilmiştir. Kraker numunelerinin renk ölçümü ve kontrol numunesi ile diğer numuneler arasındaki toplam renk farkı $\left(\Delta \mathrm{E}^{*}\right)$ hesabı, Konica Minolta Chroma Meter CR-400 renk ölçüm cihazı kullanılarak gerçekleştirilmiştir [15]. Ölçüm sonuçları CIE $\left(L^{*}, a^{*}, b^{*}\right)$ sistemi ile ifade edilmiştir.

4) Duyusal Analiz: Kek ve kraker numunelerine uygulanan duyusal analiz, 20 eğitimsiz panelist ile gerçekleştirilmiştir. Panelistlere Meilgaard ve diğg. [16] tarafından tanımlandığı şekilde, kontrole göre farklılık testi uygulanmıştır. Her örnek; panelistlerin aralarında ilişki kuramayacağı şekilde, rastgele üç haneli kod ile etiketlenmiştir. Örnekler; kontrol ile birlikte ikili gruplar halinde panelistlere sunulmuş ve kontrol ile bir diğer numunenin arasındaki farklılığı 0 ile 10 arasında puanlamaları istenmiştir. Bu puanlama 0; tamamen aynı, 10; tamamen farklı olacak şekilde gerçekleştirilmiştir.

\section{E. Istatistiksel Analiz}

Tüm ölçümler üç tekrarlı olarak gerçekleştirilmiştir. İstatistiksel analiz için SPSS (Versiyon 15, IBM, ABD) programı kullanılmıştır. Besin öğeleri kompozisyonu ve ürün kalite özellikleri arasındaki farklılıklar TekYollu ANOVA ve Scheffe Testi ile; duyusal analiz sonuçları arasındaki farklılıklar ise Dunnett Çoklu Karşılaştırma Testi ile $p<0,05$ önem düzeyinde belirlenmiştir.

\section{BULGULAR VE TARTIŞMA}

\section{A. Mercimek Unu ve Mercimek Proteini İzolatının Besin Öğeleri Kompozisyonu}

Çalışmada yerel üreticilerden temin edilip öğütülerek elde edilen mercimek ununun ve bu undan alkali ekstraksiyon/izoelektrik çöktürme metodu ile elde edilen mercimek proteini izolatının besin öğeleri kompozisyonu Tablo 3'te gösterilmiştir. Literatürde farklı mercimek türleri için belirtilen protein oranları \% 18,4-31,4 aralığında değişmektedir [6,17,18]. Çalışmamızda kullanılan mercimek ununun protein içeriği (\%26), literatürdeki çalışmalarda rapor edilen değerlere benzerlik göstermektedir. Mercimek unundan alkali ekstraksiyon/izoelektrik çöktürme metodu ile elde edilen mercimek proteini izolatının protein içeriği ise \%87,0 olarak bulunmuştur (Tablo 3). Çeşitli baklagillerden izoelektrik çöktürme metodu ile elde edilen protein izolatlarının fizikokimsayal özelliklerinin incelendiği çalışmada, mercimek protein izolatına ait protein değeri \%84,8 olarak bulunmuştur [19]. Can Karaca ve diğ. [6] yaptıkları çalışmada izoelektrik çöktürme metodu kullanılarak elde edilen mercimek proteini izolatının protein içeriğini \%81,9 olarak bulmuştur. Yağı uzaklaştırılmış mercimek unundan en yüksek verimle protein elde etmek amacıyla yürütülen bir diğer çalışmada, izoelektrik çöktürme yöntemiyle elde edilen izolatın protein miktarı \%84,1 olarak belirlenmiştir [20]. Baklagillerden protein ekstraksiyonunda çalışılan hammadde türü, ekstraksiyonda kullanılan yöntem, un:solvent oranı, sıcaklık, pH, süre gibi çalışma koşulları protein ekstraksiyon verimini etkilemekle beraber; çalışmamızda elde edilen mercimek proteini izolatının protein oranının literatürdeki çalışmalarda rapor edilen değerlere benzer olduğu görülmektedir.

Tablo 3. Mercimek unu ve mercimek proteini izolatının besin öğeleri kompozisyonu.

\begin{tabular}{|c|c|c|c|c|c|}
\hline & $\begin{array}{c}\text { Nem } \\
(\mathrm{g} / 100 \mathrm{~g})\end{array}$ & $\begin{array}{l}\text { Protein } \\
(\mathrm{g} / \mathbf{1 0 0} \mathrm{g})\end{array}$ & $\begin{array}{c}\text { Yağ } \\
(\mathbf{g} / \mathbf{1 0 0} \mathbf{g})\end{array}$ & $\begin{array}{c}\text { Karbonhidrat }^{2} \\
(\mathrm{~g} / 100 \mathrm{~g})\end{array}$ & $\begin{array}{c}\text { Kül } \\
(\mathrm{g} / \mathbf{1 0 0} \mathrm{g})\end{array}$ \\
\hline Mercimek unu & $9,4 \pm 0,1$ & $26,0 \pm 0,3$ & $1,0 \pm 0,0$ & 60,9 & $2,7 \pm 0,0$ \\
\hline Mercimek proteini izolatı & $5,6 \pm 0,3$ & $87,0 \pm 0,7$ & $0,9 \pm 0,1$ & 3,1 & $3,4 \pm 0,0$ \\
\hline
\end{tabular}

\section{B. Mercimek Proteini İzolatı İçeren Bitkisel Bazlı Kek Geliştirilmesi}

Çalışmamızda yerel üreticilerden temin edilen mercimek unundan elde edilen protein izolatı kullanılarak bitkisel bazlı kek formülasyonu geliştirilmesi amaçlanmış ve mercimek proteini izolatı oranının son ürünün çeşitli kalite özelliklerine etkileri incelenmiştir. Yumurta ve süt içeren kontrol numunesi ve bunların yerine \%1, 3 ve 5 oranında mercimek proteini izolatı içeren kek numunelerinin besin öğeleri kompozisyonu Tablo 4'te gösterilmiştir. 


\begin{tabular}{|c|c|c|}
\hline & $\begin{array}{l}\text { BŞEÜ Fen Bilimleri Dergisi } \\
7(1), 473-483,2020\end{array}$ & $\begin{array}{r}\text { BSEU Journal of Science } \\
\text { DOI: } 10.35193 / \text { bseufbd.644359 }\end{array}$ \\
\hline ERS & & $8-7575$ (http://dergipark.gov.tr/bseufbd) \\
\hline
\end{tabular}

Yumurta ve süt içeren kontrol numunesinin nem içeriğinin mercimek proteini izolatı içeren numunelerin nem içeriğinden yüksek olduğu görülmüştür $(p<0,05)$. Çalışmamıza benzer olarak, Lin ve diğ. [13] yumurta yerine bezelye protein izolatı kullanılan kekin nem içeriğinin kontrol numunesine göre düşük olduğunu gözlemlemiş ve bu sonucun baklagil proteinlerinin su tutma kapasitesinin yumurta proteinlerinden düşük olmasından kaynaklanabileceğini bildirmiştir. Çalışmamızda izolat içeren kek numunelerinde izolat oranı arttıkça nem içeriğinin düştüğü görülmüştür $(p<0,05)$. Jarpa-Parra ve diğ. [5] mercimek proteini kullanarak hazırladıkları kek hamurlarında kullanılan protein oranı arttıkça nem oranının azaldığını bildirmişlerdir. Artan protein oranı ile beraber gözlemlenen nem düşüşünün nedeninin mercimek proteininin üründeki bağlı suyun oranını artırması ve suyun serbest forma geçerek üründen uzaklaşmasını güçleştirmesi olduğu belirtilmiştir. Beklendiği üzere, formülasyona eklenen mercimek proteini izolatı oranı arttıkça kek numunelerinin protein içeriği de artmıştır. Yüzde 3 oranında mercimek protein izolatı içeren kek numunesinin protein içeriği kontrol ile benzer bulumuştur $(p>0,05)$. Yumurta ve süt içeren kontrol numunesinin yağ içeriğinin mercimek proteini izolatı içeren numunelerin yă̆ içeriğinden yüksek olduğu görülmüş $(p<0,05)$; numunelerin kül içerikleri arasında ise belirgin farklar gözlemlenmemiştir.

Tablo 4. Kek numunelerinin besin öğeleri kompozisyonu ${ }^{1}$.

\begin{tabular}{|c|c|c|c|c|c|}
\hline & $\begin{array}{c}\text { Nem } \\
(\mathrm{g} / 100 \mathrm{~g}) \\
\end{array}$ & $\begin{array}{l}\text { Protein } \\
(\mathrm{g} / 100 \mathrm{~g})\end{array}$ & $\begin{array}{c}\text { Yağ } \\
(\mathrm{g} / 100 \mathrm{~g}) \\
\end{array}$ & $\begin{array}{c}\text { Karbonhidrat }^{2} \\
(\mathrm{~g} / 100 \mathrm{~g})\end{array}$ & $\begin{array}{c}\text { Kül } \\
(\mathrm{g} / 100 \mathrm{~g}) \\
\end{array}$ \\
\hline Kontrol & $32,5 \pm 0,0^{\mathrm{a}}$ & $4,7 \pm 0,0^{b}$ & $15,2 \pm 0,1^{\mathrm{a}}$ & 46,6 & $1,0 \pm 0,0^{\mathrm{b}}$ \\
\hline$\% 1$ Mercimek proteini izolatı içeren kek & $24,2 \pm 0,6^{\mathrm{b}}$ & $3,6 \pm 0,3^{\mathrm{c}}$ & $13,3 \pm 0,2^{\mathrm{b}}$ & 57,7 & $1,2 \pm 0,0^{\mathrm{a}}$ \\
\hline$\% 3$ Mercimek proteini izolatı içeren kek & $23,3 \pm 0,6^{\mathrm{b}}$ & $4,8 \pm 0,0^{b}$ & $13,4 \pm 0,4^{\mathrm{b}}$ & 57,5 & $1,0 \pm 0,1^{\mathrm{b}}$ \\
\hline$\% 5$ Mercimek proteini izolatı içeren kek & $16,4 \pm 0,2^{\mathrm{c}}$ & $6,5 \pm 0,8^{\mathrm{a}}$ & $13,4 \pm 0,3^{\mathrm{b}}$ & 62,6 & $1,1 \pm 0,0^{\mathrm{ab}}$ \\
\hline
\end{tabular}

${ }^{1}$ Sonuçlar üç ölçümün ortalaması \pm standart sapma şeklinde rapor edilmiştir. Aynı sütun içerisinde farklı harflerle gösterilen değerler birbirlerinden istatistiksel olarak önemli düzeyde farklıdır $(p<0,05)$.

${ }^{2}$ Karbonhidrat içeriği farktan hesaplanmıştır.

Kek numunelerinin pişme ile ilgili fiziksel özellikleri Tablo 5'te gösterilmiştir. Mercimek proteini izolatı içeren kek numunelerinin hamur özgül ağırlığının kontrol numunesine göre yüksek olduğu görülmüştür $(p<0,05)$. Çalışmamıza benzer sonuçlar mercimek proteini izolatı [5] ve soya proteini izolatı [13] içeren kekler için de rapor edilmiş ve özgül ağırlıktaki artışın hamura giren hava girişinin azaldığının göstergesi olduğu bildirilmiştir. Bu olgunun baklagillerden elde edilen proteinlerinin köpük oluşturma kapasitesinin yumurta proteinlerinden düşük olmasından kaynaklanabileceği ifade edilmiştir. Mercimek proteini izolatı içeren numunelerin kek veriminin kontrole göre düşük olduğu ve pişme kaybının kontrolden yüksek olduğu görülmüştür $(p<0,05)$. İzolat içeren numuneler içerisinde artan izolat oranına bağlı bir trend gözlemlenmemiştir $(p>0,05)$. Kek verimi hamurdan uzaklaşan su ile azaldığından, izolat içeren numunelerde gözlenen düşük verim, mercimek proteini izolatının su tutma kapasitesinin yumurta proteinlerinden düşük olmasına işaret etmektedir. Kek yüksekliği değerleri incelendiğinde, $\% 3$ ve 5 oranında izolat içeren numunelerin yüksekliğinin kontrole yakın olduğu görülmüştür. Kek yüksekliğindeki iyileşme, artan protein oranı ile hamurun viskoelastik özelliklerinin gelişmesi ve ürünün çırpma sırasında daha fazla hava tutması ile ilişkilendirilmektedir [21].

Tablo 5. Kek numunelerinin fiziksel özellikleri ${ }^{1}$.

\begin{tabular}{lcccc}
\hline & $\begin{array}{c}\text { Hamur Özgül } \\
\text { Ağırlığı }\end{array}$ & $\begin{array}{c}\text { Kek Verimi } \\
(\%)\end{array}$ & $\begin{array}{c}\text { Pişme Kaybı } \\
(\%)\end{array}$ & Yükseklik (mm) \\
\hline Kontrol & $1,22 \pm 0,02^{\mathrm{c}}$ & $90,7 \pm 0,1^{\mathrm{a}}$ & $9,3 \pm 0,1^{\mathrm{b}}$ & $25,3 \pm 0,6^{\mathrm{ab}}$ \\
\%1 Mercimek proteini izolatı içeren kek & $1,35 \pm 0,00^{\mathrm{b}}$ & $85,1 \pm 0,1^{\mathrm{b}}$ & $14,9 \pm 0,1^{\mathrm{a}}$ & $23,3 \pm 0,6^{\mathrm{c}}$ \\
\%3 Mercimek proteini izolatı içeren kek & $1,37 \pm 0,00^{\mathrm{b}}$ & $85,4 \pm 0,1^{\mathrm{b}}$ & $14,6 \pm 0,1^{\mathrm{a}}$ & $24,7 \pm 0,6^{\mathrm{bc}}$ \\
$\% 5$ Mercimek proteini izolatı içeren kek & $1,56 \pm 0,01^{\mathrm{a}}$ & $85,4 \pm 0,2^{\mathrm{b}}$ & $14,6 \pm 0,2^{\mathrm{a}}$ & $26,3 \pm 0,6^{\mathrm{a}}$ \\
\hline
\end{tabular}

1 Sonuçlar üç ölçümün ortalaması \pm standart sapma şeklinde rapor edilmiştir. Aynı sütun içerisinde farklı harflerle gösterilen değerler birbirlerinden istatistiksel olarak önemli düzeyde farklıdır $(p<0,05)$. 
Kek numunelerinin kabuk ve iç kısımlarına ait renk parametreleri ve esmerleşme indeksi değerleri Tablo 6'da gösterilmiştir. Ölçümde kullanılan CIE renk parametreleri $L^{*}\left(L^{*}=0\right.$; siyah ve $L^{*}=100$; beyaz), $a^{*}\left(-a^{*}\right.$; yeşillik ve $+a^{*}$; kırmızılık) ve $\mathrm{b}^{*}\left(-b^{*}\right.$; mavilik ve $+b^{*}$; sarılık) değerleridir [22]. Mercimek proteini izolatı içeren kek numunelerinde, özellikle \%3 ve 5 oranında izolat içerenlerde kek kabuğunun ve içinin $L^{*}$ değerinin kontrolden düşük olduğu $(p<0,05)$; dolayısıyla siyaha yakınlığın arttığı görülmüştür. Benzer sonuçlar bezelye proteini izolatı [13], mercimek proteini izolatı [5] ve mercimek unu [23] içeren kekler için de rapor edilmiştir. Yine izolat içeren keklerde izolat oranı arttıkça özellikle kabukta $a^{*}$ ve $b^{*}$ değerlerinin düştüğü; bir başka deyişle kabuğun daha az kırmızımsı ve sarımsı bir görünüm aldığı gözlemlenmiştir. Baklagil proteini içeren keklerde kabuk renginin Maillard reaksiyonundan ve pişirme sırasında gerçekleşen karamelizasyondan etkilendiği bildirilmiştir [13]. Kontrol numunesi ile farklı oranlarda izolat içeren kek numunelerinin arasındaki renk farkı $\left(\Delta E^{*}\right)$ formülasyonda kullanılan izolat oranından etkilenmiştir. Kontrol numunesi ile diğer numuneler arasındaki $\Delta E^{*}$ değeri 3 ve üzerinde ise renk farkının insan gözü ile algılanabilecek düzeyde olduğu belirtilmektedir [5]. Özellikle \%3 ve 5 oranında izolat içeren numuneler için renk farkı gözle ayırt edilebilecek düzeydedir. Formülasyondaki izolat oranı arttıkça hem kek kabuğu hem de içi için renk farkının arttığı görülmüştür $(p<0,05)$. Kontrol numunesi ile \%1 ve 3 oranında izolat içeren numunelerin kabuk ve iç kısımları için ölçülen esmerleşme indeksi değerleri benzer bulunmuştur $(p>0,05)$. En yüksek oranda izolat içeren numunenin kabuk kısmı için ölçülen esmerleşme indeksi ise diğer numunelerden düşük bulunmuştur $(p<0,05)$. Kek hamurunun yapisında bulunan hava miktarının ve fırının içinde gerçekleşen genleşmenin kararma oranını düşürebileceği ve son ürünün kabuk rengini etkileyebileceği bildirilmiştir [14]. Bu bağlamda \%5 oranında izolat içeren numunenin yüksek protein içeriğinin (Tablo 4) hamurda tutulan hava miktarının artmasında etkili olduğu düşünülmektedir. Bu numunenin yüksekliğinin diğerlerinden yüksek olması da (Tablo 5) bu olguyu destekleyici niteliktedir.

Tablo 6. Kek numunelerinin renk parametreleri ${ }^{1}$.

\begin{tabular}{|c|c|c|c|c|c|}
\hline & $L^{*}$ & $a^{*}$ & $b^{*}$ & $\Delta E^{*}$ & $\begin{array}{c}\text { Esmerleşme } \\
\text { indeksi }\end{array}$ \\
\hline \multicolumn{6}{|l|}{ Kontrol } \\
\hline Kabuk & $28,71 \pm 0,23^{\mathrm{a}}$ & $9,13 \pm 0,17^{\mathrm{a}}$ & $9,60 \pm 0,26^{\mathrm{a}}$ & - & $63,11 \pm 1,04^{\mathrm{a}}$ \\
\hline İç & $20,26 \pm 0,72^{\mathrm{c}}$ & $9,65 \pm 0,28^{\mathrm{d}}$ & $10,65 \pm 0,40^{c}$ & - & $106,28 \pm 3,67^{\mathrm{cd}}$ \\
\hline \multicolumn{6}{|c|}{$\% 1$ Mercimek proteini izolatı içeren kek } \\
\hline Kabuk & $28,56 \pm 0,96^{\mathrm{ab}}$ & $8,92 \pm 0,10^{\mathrm{a}}$ & $9,17 \pm 0,40^{\mathrm{ab}}$ & $0,95^{\mathrm{b}}$ & $60,90 \pm 4,59^{a}$ \\
\hline İç & $19,49 \pm 0,69^{c}$ & $9,49 \pm 0,17^{\mathrm{d}}$ & $9,68 \pm 0,18^{d}$ & $1,33^{\mathrm{d}}$ & $101,56 \pm 3,72^{\mathrm{d}}$ \\
\hline \multicolumn{6}{|c|}{$\% 3$ Mercimek proteini izolatı içeren kek } \\
\hline Kabuk & $26,91 \pm 0,65^{b}$ & $8,31 \pm 0,02^{\mathrm{b}}$ & $9,14 \pm 0,14^{\mathrm{ab}}$ & $2,04^{\mathrm{b}}$ & $63,27 \pm 1,10^{\mathrm{a}}$ \\
\hline İç & $17,12 \pm 0,21^{\mathrm{d}}$ & $9,22 \pm 0,28^{\mathrm{d}}$ & $9,03 \pm 0,09^{\mathrm{d}}$ & $3,57^{\mathrm{cd}}$ & $110,67 \pm 3,06^{\mathrm{cd}}$ \\
\hline \multicolumn{6}{|c|}{$\% 5$ Mercimek proteini izolatı içeren kek } \\
\hline Kabuk & $26,85 \pm 0,19^{b}$ & $5,51 \pm 0,17^{\mathrm{c}}$ & $8,62 \pm 0,02^{\mathrm{b}}$ & $4,20^{\mathrm{a}}$ & $53,21 \pm 0,30^{\mathrm{b}}$ \\
\hline İç & $16,65 \pm 0,43^{\mathrm{d}}$ & $9,78 \pm 0,71^{\mathrm{d}}$ & $8,99 \pm 0,46^{\mathrm{d}}$ & $4,07^{\mathrm{c}}$ & $116,10 \pm 5,71^{\mathrm{c}}$ \\
\hline
\end{tabular}

${ }^{1}$ Sonuçlar üç ölçümün ortalaması \pm standart sapma şeklinde rapor edilmiştir. Aynı sütun içerisinde farklı harflerle gösterilen değerler birbirlerinden istatistiksel olarak önemli düzeyde farklıdır $(p<0,05)$.

Kek numunelerinin tekstür analizi sonuçları Tablo 7'de gösterilmiştir. Kekte mercimek proteini izolatı uygulaması ürünün tekstür özelliklerinde farklılıklara neden olmuştur. Çalışmamızda \%3 ve 5 oranında mercimek proteini izolatı içeren kek numunelerinin sertlik değerinin kontrol numunesinden yüksek olduğu görülmüştür $(p<0,05)$. Gözlemimize benzer olarak, nohut proteini izolatı [14] ve çeşitli baklagil unları [24] ilave edilen keklerde baklagil proteini veya ununun miktarı arttıkça sertlik değerinin de arttığı bildirilmiştir. Kohezyon kapasitesi gıdanın mekanik etki altında deformasyon derecesi ile ilişkilidir. Kohezyon kapasitesi ve esnekliğin, ürün formülasyonunda bulunan proteinlerin geliştirdiği elastik ă̆ yapıdan etkilendiği bildirilmiştir [25, 26]. Çalışmamızda mercimek proteini izolatı içeren kek numunelerinin kohezyon kapasitesi, esneklik ve çiğnenebilirlik değerlerinin kontrol numunesine göre düşük olduğu görülmüştür $(p<0,05)$. İzolat içeren numuneler kendi aralarında değerlendirdiğinde ise $\% 5$ oranında izolat içeren numunenin kohezyon kapasitesi, esneklik ve çiğnenebilirlik değerlerinin diğerlerinden yüksek olduğu görülmektedir $(p<0,05)$. Kek numunelerinin katılık değerleri de sertlik değerleri ile benzer bir eğilim göstermiş; izolat içeren kek numunelerinin sertlik değeri kontrol numunesinden yüksek bulunmuştur $(p<0,05)$. Çalışmamızda kullanılan formülasyona göre kekte mercimek 
proteini izolatı kullanımı daha sert ve katı; ancak esnekliği ve çiğnenebilirliği düşük bir yapı oluşturmuştur. Mercimek proteini izolatı içeren kek formülasyonlarının tekstür özellikleri açısından iyileştirmeye açık olduğu görülmektedir.

Tablo 7. Kek numunelerinin tekstür özellikleri ${ }^{1}$.

\begin{tabular}{|c|c|c|c|c|c|}
\hline & $\begin{array}{c}\text { Sertlik } \\
\text { (gf) }\end{array}$ & $\begin{array}{l}\text { Kohezyon } \\
\text { Kapasitesi } \\
\end{array}$ & $\begin{array}{c}\text { Esneklik } \\
(\mathbf{m m})\end{array}$ & $\begin{array}{c}\text { Çiğnenebilirlik } \\
(\mathrm{Nmm})\end{array}$ & $\begin{array}{c}\begin{array}{c}\text { Katılık } \\
(\mathrm{kgf} / \mathrm{mm})\end{array} \\
\end{array}$ \\
\hline Kontrol & $375,92 \pm 20,62^{\mathrm{a}}$ & $0,40 \pm 0,01^{\mathrm{a}}$ & $4,54 \pm 0,16^{\mathrm{a}}$ & $9,89 \pm 0,48^{\mathrm{a}}$ & $0,06 \pm 0,00^{\circ}$ \\
\hline$\% 1$ Mercimek proteini izolatı içeren kek & $424,58 \pm 24,99^{a}$ & $0,17 \pm 0,01^{\mathrm{c}}$ & $2,30 \pm 0,21^{\mathrm{c}}$ & $1,57 \pm 0,15^{\mathrm{c}}$ & $0,19 \pm 0,01^{\mathrm{b}}$ \\
\hline$\% 3$ Mercimek proteini izolatı içeren kek & $582,16 \pm 52,25^{\mathrm{b}}$ & $0,12 \pm 0,00^{\mathrm{d}}$ & $2,13 \pm 0,10^{c}$ & $1,29 \pm 0,11^{\mathrm{c}}$ & $0,19 \pm 0,01^{\mathrm{b}}$ \\
\hline$\% 5$ Mercimek proteini izolatı içeren kek & $621,11 \pm 48,18^{b}$ & $0,24 \pm 0,01^{\mathrm{b}}$ & $2,82 \pm 0,15^{\mathrm{b}}$ & $2,94 \pm 0,21^{\mathrm{b}}$ & $0,40 \pm 0,02^{a}$ \\
\hline
\end{tabular}

Çalışmamızda 20 eğitimsiz panelist ile gerçekleştirilen kontrole göre farklılık testinde mercimek proteini izolatı içeren kek numuneleri kontrol numunesinden farklı bulunmuştur $(p<0,05)$. Panelistler tarafından algılanan farkta izolat içeren keklerin nem ve yağ içeriğinin (Tablo 4), renginin (Tablo 6) ve tekstür özelliklerinin (Tablo 7) kontrolden farklı olmasının etkili olduğu düşünülmektedir. Bu bakımdan mercimek proteini izolatı içeren bitkisel bazlı kek formülasyonlarının iyileştirmeye açık olduğu görülmektedir.

\section{Mercimek Unu İçeren Bitkisel Bazlı Kraker Geliştirilmesi}

Çalışmamızda yerel üreticilerden temin edilen mercimek unu kullanılarak bitkisel bazlı kraker formülasyonu geliştirilmesi amaçlanmış ve mercimek unu oranının son ürünün çeşitli kalite özellikleri üzerindeki etkileri incelenmiştir. Kontrol numunesi olarak buğday unu içeren ve buğday ununu belirli oranlarda ikame edecek şekilde; \%20, 40 ve 50 oranında mercimek unu içeren kraker numunelerinin besin öğeleri kompozisyonu Tablo 8 'de gösterilmiştir. Kontrol numunesi ile en düşük oranda (\%20) mercimek unu içeren kraker numunesinin nem içerikleri benzer bulunmuştur $(p>0,05)$. Mercimek proteini izolatı içeren kek numunelerinde gözlenen trende benzer olarak; kraker formülasyonunda kullanılan mercimek unu oranı arttıkça numunelerin protein oranının arttığı ve nem içeriğinin düştüğü görülmektedir $(p<0,05)$. Artan protein oranı ile beraber gözlemlenen nem düşüşünün nedeni literatürde baklagil proteinlerinin üründeki bağlı suyun oranını artırmasına dayandırılmaktadır [13]. Kontrol numunesinin yağ içeriğinin $\% 40$ ve 50 oranında mercimek unu içeren numunelerin yağ içeriğinden yüksek olduğu görülmüştür $(p<0,05)$. Bu bulgu mercimek ununun yağ tutma kapasitesinin buğday unundan düşük olduğuna işaret etmektedir. Mercimek unu içeren kraker numunelerinin ve kontrol numunesinin kül içerikleri arasında ise belirgin farklar gözlemlenmemiştir $(p>0,05)$.

Tablo 8. Kraker numunelerinin besin öğeleri kompozisyonu ${ }^{1}$.

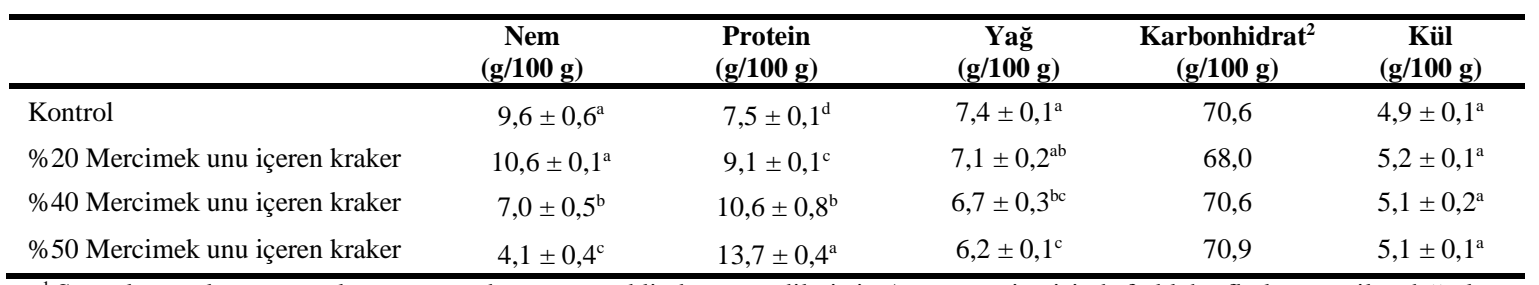

${ }^{1}$ Sonuçlar üç ölçümün ortalaması \pm standart sapma şeklinde rapor edilmiştir. Aynı sütun içerisinde farklı harflerle gösterilen değerler birbirlerinden istatistiksel olarak önemli düzeyde farklıdır $(p<0,05)$.

${ }^{2}$ Karbonhidrat içeriği farktan hesaplanmıştır.

Kraker numunelerinin renk parametreleri ve esmerleşme indeksi değerleri Tablo 9'da gösterilmiştir. Mercimek unu içeren kraker numunelerinin $L^{*}$ değerinin kontrolden düşük olduğu $(p<0,05)$; dolayısıyla siyaha yakınlığın arttığı görülmüştür. Kraker formülasyonunda kullanılan mercimek unu miktarı $\operatorname{arttıkça~} L^{*}$ değerinin de düştüğü görülmektedir. Mercimek unu içeren numunelerde mercimek unu oranı $\operatorname{arttıkça~} a^{*}$ değerinin $\operatorname{arttığ1~ve~} b^{*}$ 
değerinin düştüğü; bir diğer deyişle ürünün daha kırmızımsı ve sarımsı bir renk aldığı görülmüştür. Mercimek unu içeren tüm kraker numuneleri için kontrol numunesi ile aralarındaki renk farkı gözle ayırt edilebilecek düzeydedir $\left(\Delta E^{*}>3\right)$. Kraker formülasyonunda kullanılan mercimek unu oranı arttıkça bu renk farkının da arttığ görülmektedir $(p<0,05)$.

Tablo 9. Kraker numunelerinin renk parametreleri ${ }^{1}$.

\begin{tabular}{lcccc}
\hline & $\boldsymbol{L}^{*}$ & $\boldsymbol{a}^{*}$ & $\boldsymbol{b}^{*}$ & $\boldsymbol{A E}^{*}$ \\
\hline Kontrol & $47,31 \pm 0,60^{\mathrm{a}}$ & $6,14 \pm 0,25^{\mathrm{b}}$ & $16,36 \pm 0,63^{\mathrm{a}}$ & - \\
\%20 Mercimek unu içeren kraker & $40,25 \pm 1,37^{\mathrm{b}}$ & $6,19 \pm 0,29^{\mathrm{b}}$ & $14,61 \pm 0,45^{\mathrm{b}}$ & $7,28^{\mathrm{a}}$ \\
\%40 Mercimek unu içeren kraker & $39,11 \pm 0,76^{\mathrm{b}}$ & $7,10 \pm 0,05^{\mathrm{a}}$ & $13,73 \pm 0,65^{\mathrm{b}}$ & $8,70^{\mathrm{a}}$ \\
\%50 Mercimek unu içeren kraker & $35,68 \pm 0,80^{\mathrm{c}}$ & $6,70 \pm 0,16^{\mathrm{ab}}$ & $11,85 \pm 0,42^{\mathrm{c}}$ & $12,49^{\mathrm{b}}$ \\
\hline
\end{tabular}

${ }^{1}$ Sonuçlar üç ölçümün ortalaması \pm standart sapma şeklinde rapor edilmiştir. Aynı sütun içerisinde farklı harflerle gösterilen değerler birbirlerinden istatistiksel olarak önemli düzeyde farklıdır $(p<0,05)$.

Kraker numunelerinin tekstür analizi sonuçları Tablo 10'da gösterilmiştir. Çalışmamızda kullanılan kraker formülasyonunda buğday ununun belirli oranlarda mercimek unu ile ikame edilmesi ürünün tekstür özelliklerinde farklılıklara neden olmuştur. Mercimek unu içeren kraker numunelerinin sertlik ve katılık değerlerinin kontrol numunesinden düşük olduğu görülmüştür $(p<0,05)$. Gıdanın mekanik etki altında göreceği deformasyonun derecesini gösteren kohezyon kapasitesi ise kontrole göre farklı bulunmakla beraber; mercimek unu miktarına bağlı bir trend gözlemlenmemiştir. Mercimek unu içeren kraker numunelerinin esneklik değerleri kontrole göre yüksek; çiğnenebilirlik değerleri ise kontrolden düşük bulunmuştur $(p<0,05)$. Çalışmamızda kullanılan formülasyona göre krakerde mercimek unu kullanımı daha yumuşak ve esnek; fakat çiğnenebilirliği düşük bir yapı oluşturmuştur. Son olarak, eğitimsiz panelistler ile gerçekleştirilen kontrole göre farklılık testine göre, \%20 ve 40 oranında mercimek unu içeren kraker numuneleri renk ve tekstür özelliklerinde tespit edilen farklılıklara rağmen, duyusal özellikleri açısından kontrol numunesine benzer bulunmuştur $(p>0,05)$. Buğday ununun mercimek unu ile en yüksek oranda (\%50) ikame edildiği numune ise panelistlerce kontrolden farklı algılanmıştır.

Tablo 10. Kraker numunelerinin tekstür özellikleri ${ }^{1}$.

\begin{tabular}{|c|c|c|c|c|c|}
\hline & $\begin{array}{c}\text { Sertlik } \\
\text { (gf) }\end{array}$ & $\begin{array}{c}\text { Kohezyon } \\
\text { Kapasitesi }\end{array}$ & $\begin{array}{c}\text { Esneklik } \\
(\mathrm{mm})\end{array}$ & $\begin{array}{c}\text { Çiğnenebilirlik } \\
(\mathrm{Nmm})\end{array}$ & $\begin{array}{c}\text { Katılık } \\
(\mathrm{kgf} / \mathrm{mm})\end{array}$ \\
\hline Kontrol & $5319,3 \pm 172,6^{\mathrm{a}}$ & $0,09 \pm 0,00^{\mathrm{b}}$ & $0,35 \pm 0,03^{\mathrm{c}}$ & $3,11 \pm 0,16^{\mathrm{a}}$ & $9,53 \pm 0,45^{\mathrm{a}}$ \\
\hline \%20 Mercimek unu içeren kraker & $2051,8 \pm 158,4^{\mathrm{c}}$ & $0,13 \pm 0,01^{\mathrm{a}}$ & $0,54 \pm 0,01^{\mathrm{a}}$ & $1,57 \pm 0,06^{\mathrm{b}}$ & $7,31 \pm 0,42^{b}$ \\
\hline$\% 40$ Mercimek unu içeren kraker & $2473,1 \pm 71,7^{\mathrm{b}}$ & $0,13 \pm 0,01^{\mathrm{a}}$ & $0,49 \pm 0,01^{\mathrm{ab}}$ & $1,09 \pm 0,08^{\mathrm{c}}$ & $4,25 \pm 0,29^{c}$ \\
\hline$\% 50$ Mercimek unu içeren kraker & $2133,3 \pm 143,5^{b c}$ & $0,06 \pm 0,01^{\mathrm{c}}$ & $0,47 \pm 0,01^{\mathrm{b}}$ & $0,60 \pm 0,05^{\mathrm{d}}$ & $5,30 \pm 0,14^{\mathrm{d}}$ \\
\hline
\end{tabular}

\section{SONUÇ}

Bu çalışmada mercimek unu ve bu undan alkali ekstraksiyon/izoelektrik çöktürme metodu ile elde edilen protein izolatının iki farklı fırıncılık ürünün kalite özelliklerine etkileri incelenmiştir. Mercimek proteini izolatı kek formülasyonunda yumurta ve süt yerine kullanılmıştır. Kraker formülasyonunda ise buğday unu belirli oranlarda mercimek unu ile ikame edilmiştir. Mercimek proteini içeren kek numunelerinin renk ve tekstür özelliklerinin kontrol numunesinden farklı olduğu görülmüştür. Duyusal analiz değerlendirmelerine göre de kekte mercimek proteini izolatı kullanımı tüketici tarafından hissedilebilir bir fark yaratmıştır. Bu açıdan mercimek proteini izolatı içeren bitkisel bazlı kek formülasyonlarının iyileştirmeye ihtiyaç duyduğu görülmüştür. Öte yandan, buğday ununun \%20 ve 40 oranında mercimek unu ila ikame edildiği kraker numunelerinde renk ve tekstür özellikleri kontrolden farklı olmasına karışılık numuneler duyusal özellikler bakımından kontrole benzer bulunmuştur. Bu çalışma sonucu elde edilen bulgular, ülkemize özgü mercimek türlerinin ve bunlardan elde edilen proteince zengin bileşenlerin çeşitli fırıncılık ürünlerinde formülasyonlarda modifikasyon yapılarak bitkisel protein kaynağı olarak kullanılabileceğini göstermiştir. 


\section{KAYNAKLAR}

[1] Boye, J., Zare, F., \& Pletch, A. (2010). Pulse proteins: Processing, characterization, functional properties and applications in food and feed. Food Research International, 43, 414-431.

[2] Türkiye İstatistik Kurumu (2018). http://www.tuik.gov.tr.

[3] Roy, F., Boye, J. I., \& Simpson, B. K. (2010). Bioactive proteins and peptides in pulse crops: Pea, chickpea and lentil, Food Research International, 43, 432-442.

[4] Bhatty, R. S. (1984). Relationship between physical and chemical characters and cooking quality in lentil. Journal of Agricultural and Food Chemistry, 32, 1161-1166.

[5] Jarpa-Parra, M., Wong, L., Wismer, W., Temelli, F., Han, J., Huang, W., Eckhart, E., Tian, Z., Shi, K., Sun, T., \& Chen, L. (2017). Quality characteristics of angel food cake and muffin using lentil protein as egg/milk replacer. International Journal of Food Science \& Technology, 52, 1604-1613.

[6] Can Karaca, A., Low, N., \& Nickerson, M. (2011). Emulsifying properties of chickpea, faba bean, lentil and pea proteins produced by isoelectric precipitation and salt extraction. Food Research International, 44, 27422750 .

[7] Joshi, M., Adhikari, B., Aldred, P., Panozzo, J. F., \& Kasapis, S. (2011). Physicochemical and functional properties of lentil protein isolates prepared by different drying methods, Food Chemistry, 129, 1513-1522.

[8] Millar, K. A., Barry-Ryan, C., Burke, R., Hussey, K., McCarthy, S., \& Gallagher, E. (2017). Effect of pulse flours on the physiochemical characteristics and sensory acceptance of baked crackers, International Journal of Food Science and Technology, 52, 1155-1163.

[9] AOAC. (1990). Official Methods of Analysis, Association of Official Analytical Chemists, Arlington, VA., USA.

[10] Paraskevopoulou, A., Donsouzi, S., Nikiforidis, C., \& Kiosseoglou, V. (2015). Quality characteristics of eggreduced pound cakes following WPI and emulsifier incorporation. Food Research International, 69, 72-79.

[11] Palamutoğlu, R., Kasnak, C. \& Moral B. (2018). Şeker ikamesi olarak stevya estraktı kullanımının keklerin bazı fiziksel ve duyusal özellikleri üzerine etkisi. Karadeniz Fen Bilimleri Dergisi, 8, 98-108.

[12] Ratnayake, W. S ., Geera, B., \& Rybak, D. A. (2012). Effects of egg and egg replacers on yellow cake product quality. Journal of Food Processing and Preservation, 36, 21-29.

[13] Lin, M., Tay, S. H., Yang, H., Yang, B. \& Li, H. (2017). Development of eggless cakes suitable for lactovegetarians using isolated pea proteins. Food Hydrocolloids, 69, 440-449.

[14] Shaabani, S., Yarmand, M. S., Kiani, H., \& Emam-Djomeh, Z. (2018). The effect of chickpea protein isolate in combination with transglutaminase and xanthan on the physical and rheological characteristics of gluten free muffins and batter based on millet flour. LWT - Food Science and Technology, 90, 362-372.

[15] Millar, K. A., Barry-Ryan, C., Burke, R., Hussey, K., McCarthy, S., \& Gallagher, E. (2017). Effect of pulse flours on the physiochemical characteristics and sensory acceptance of baked crackers. International Journal of Food Science and Technology, 52, 1155-1163.

[16] Meilgaard, M., Civille, G. V., \& Carr, B. T. (2007). Sensory Evaluation Techniques, CRC Press, Taylor \& Francis Group, Boca Raton, 92-100.

[17] El-Adawy, T. A., Rahma, E. H., El-Bedawey, A. A., \& El-Beltagy, A. E. (2003). Nutritional potential and functional properties of germinated mung bean, pea and lentil seeds. Plant Foods for Human Nutrition, 58, $1-13$. 
[18] Costa, G. E. A, Queiroz-Monici, K. S., Reis, S. M. P. \& Oliveira, A. C. (2006). Chemical composition, dietary fibre and resistant starch contents of raw and cooked pea, common bean, chickpea and lentil legumes. Food Chemistry, 94, 327-330.

[19] Ladjal Ettoumi, Y. \& Chibane, M. (2015). Some physicochemical and functional properties of pea, chickpea and lentil whole flours. International Food Research Journal, 22, 987-996.

[20] Ko, T. L., Soe Than, S., \& Oo, Z. Z. (2017). Isolation of protein from defatted lentil flour. American Journal of Food Science and Technology, 5, 238-244.

[21] Shevkani, K. \& Singh, N. (2014). Influence of kidney bean, field pea and amaranth protein isolates on the characteristics of starch-based gluten-free muffins. International Journal of Food Science \& Technology, 49, 2237-2244.

[22] Baixauli, R., Salvador, A., \& Fiszman, S. (2008). Textural and colour changes during stroage and sensory shelf life of muffins containing resistant starch. European Food Research and Technology, 226, 523-530.

[23] Hera, E., Ruiz- Paris, E., Oliete, B., \& Gomez, M. (2012). Studies of the quality of cakes made with wheatlentil composite flours. LWT - Food Science and Technology, 49, 48-54.

[24] Gularte, M. A., Gomez, M., \& Rosell, C. M. (2012). Impact of legume flours on quality and in vitro digestibility of starch and protein from gluten-free cakes. Food and Bioprocess Technology, 5, 3142-3150.

[25] Wilderjans, E., Pareyt, B., Goesaert, H., Brijs, K., \& Delcour, J. A. (2008). The role of gluten in a pound cake system: A model approach based on gluten-starch blends. Food Chemistry, 110, 909-915.

[26] Moore, M. M., Schober, T. J., Dockery, P., \& Arendt, E. K. (2004). Textural comparisons of gluten-free and wheat-based doughs, batters, and breads. Cereal Chemistry, 81, 567-575. 